Int. J. Electrochem. Sci., 15 (2020) $9874-9887$

International Journal of

ELECTROCHEMICAL

SCIENCE

www.electrochemsci.org

\title{
Influence of Zinc and Aluminum Simultaneous Injection on Corrosion Behavior and Semiconducting Properties of Oxide Film on 304L
}

\author{
Shenghan Zhang* , Chenhao Sun, Yu Tan \\ Hebei Key Lab of Power Plant Flue Gas Multi-Pollutants Control, Department of Environment \\ Science and Engineering, North China Electric Power University, Baoding, 071003, PR China; \\ Environmental Systems Optimization, College of Environmental Science and Engineering, North \\ China Electric Power University, Beijing, 102206, PR China \\ *E-mail: shenghan_zhang@126.com
}

doi: $10.20964 / 2020.10 .62$

Received: 15 June 2020 / Accepted: 2 August 2020 / Published: 31 August 2020

\begin{abstract}
Zinc and aluminum simultaneous injection technology aim to reduce the cost and potential radioactivity of traditional zinc injection technology by replacing a portion of the zinc used with aluminum. Oxide films on 304L SS were formed in a high-temperature water environment under simultaneous injection of zinc and aluminum, and their corrosion behavior and semiconducting properties were studied by potentiodynamic scanning, EIS, Mott-Schottky curve, SEM, XPS and GI-XRD analysis. The results showed that the oxide film formed by simultaneous injection of zinc and aluminum had a lower corrosion current and higher impedance; additionally, it had a more compact appearance and changes in its semiconducting properties. The corrosion resistance and stability of the oxide film were enhanced through injection of zinc and aluminum. Both zinc and aluminum were involved in the formation reactions of the oxide film and formed spinel phases of $\mathrm{ZnAl}_{2} \mathrm{O}_{4}$ and $\mathrm{ZnFe}_{2} \mathrm{O}_{4}$. In addition, a point defect model (PDM) was employed to microscopically describe the formation process of $\mathrm{ZnAl}_{2} \mathrm{O}_{4}$ in the oxide film and the change of semiconducting properties.
\end{abstract}

Keywords: Zinc and Aluminum Simultaneous Injection; 304L SS; Corrosion Behavior; Point Defect Model.

\section{FULL TEXT}

(C) 2020 The Authors. Published by ESG (www.electrochemsci.org). This article is an open access article distributed under the terms and conditions of the Creative Commons Attribution license (http://creativecommons.org/licenses/by/4.0/). 